\title{
Discussion on the legal clinic for the protection of the rights and interests of the disabled
}

\author{
Hui Ma , JiZhou Yang \\ College of Arts and Law of Wuhan University of Technology ,Wuhan Hubei ,430070, China \\ *email: ff6453@sohu.com
}

\begin{abstract}
As a new mode of practice teaching, the law can not only help the Law School of theoretical knowledge into practical ability, but also to provide legal aid for vulnerable groups. This paper put forward a tentative idea on the construction of "the protection of the rights and interests of legal clinic" which is a new legal clinic, in order to promote the continuous improvement of China's legal clinic education.
\end{abstract}

Keywords: legal clinic, legal aid, protection of the rights and interests of the disabled.

\section{The origin of a disability rights protection legal clinic}

Legal clinic is a new method of education originated in the United states. This method of education is generated from the medical clinic education mode. In medical school students need to spend considerable time in clinical medicine, diagnosis and treatment will be from practice. When introducing the teaching method of law education, law school cited "clinic" in the title, it produced a unique name legal clinic "this law field. The disabled rights protection law, as the name suggests, is a dedicated to the protection of the rights and interests of the disabled as the goal of the new legal clinic. The difference between the disabled rights protection law clinic and other legal clinic is the protection of the rights and interests of the disabled as a center, more professional and normative. Legal clinic to protect the interests of persons with disabilities is mainly through the form of legal aid to help the disabled, with ties to the community more closely, in view of this, legal clinic to protect the interests of persons with disabilities will be conversion of legal education is a out of law school fence outside the service in the form of community.

The protection of the rights and interests of legal clinic has its practical basis. First of all, building a legal clinic for the protection of the rights and interests of the disabled is the requirement of the principle of equality of human rights. Constructing the legal clinic to protect the interests of persons with disabilities, in full respect for the disabled of the equality of human rights under the premise, through the legal aid in the form of effort to helping the disabled people to solve legal problems, realize the development in an all-round way, the real guarantee for people with disability rights and right to development and other basic human rights. Therefore, we should actively build a legal clinic for the protection of the rights and interests of persons with disabilities in order to make due contributions to the equality of human rights in our country. Secondly, constructing the legal clinic for the protection of the rights and interests of the disabled is the embodiment of social fairness and justice. As a social vulnerable group, the disabled people's ability to take care of themselves is poor, the right to subsistence and development is highly vulnerable to abuse. Therefore, the state, society and individuals should actively take measures to protect the legitimate rights and interests of the disabled. To establish and improve the legal clinics of the rights and interests of persons with disabilities can not only protect the rights and interests of the people with disabilities, but also guarantee the enjoyment of the rights and interests of the people in the life of the people in the social life. 


\section{Construction of the rights and interests of persons with disabilities to protect the specific idea of the clinic}

\section{(1) the design concept of the legal clinic for the protection of the rights and interests of the disabled}

The rights and interests protection of the disabled has its own unique design concept, that is, sharing, public service, innovation and construction. Share with others is the original meaning of common use, enjoy and exercise. Specific to the disabled rights and interests protection law clinic construction, we cannot geese are swans, but to actively and our other legal clinic cooperate, communicate actively made in clinic construction achievements and encountered problems, to achieve common development. "Public welfare" is a new word which appears after the five four movement of our country. The public can be said to be one of the important concept of disability rights protection legal clinic. Legal clinic as a new mode of education in social welfare undertakings have very high value. Law clinic students through to provide legal aid to disabled people, not only can increase their ability of practice, and can put its professional knowledge to serve the society and to provide convenience for the rights of the disabled in China, plays a positive role in the protection of interests of disabled people in our country. Legal clinic to protect the interests of persons with disabilities a feature is the innovation, the construction of the special protection of the rights and interests of persons with disabilities legal clinic itself is an innovation and in the construction of the legal clinic, in order to meet the need of protection of the rights and interests of persons with disabilities, clinics in the mode of service a new is also essential. To build the legal clinic to protect the interests of the disabled and improve the development necessary concept, disabled rights and interests protection law clinic and the federations at all levels and legal aid agencies have natural fusion, and federations at all levels to set up a joint special thought disabled legal aid for the purpose of external legal service provided mechanism can not only solve the problem of lack of legal clinics may, and can contribute to a disabled protection in our country.

\section{(2) the protection of the rights and interests of legal clinic service system}

Construction of disability rights protection law, must build a standardized, professional service system. First, the clinic students should have good psychological quality, good communication skills and the disabled. Relatively normal disabled people is more sensitive in its communication should be more understanding and patience, but this does not mean that we are in communication with the disabled can see themselves as "strong", ignore disabled the ability, to the mentality of the mercy and disabled to communicate. Too much of the segment, but will make each other to form a psychological condition, so that the communication obstacles and limitations. Therefore, the breakthrough and premise of good communication is the superiority of the disabled psychological self, communicate with equal attitude and disabled. And the second premise is to maintain good communication with cheerful, optimistic. Whether with able-bodied or disabled people, As long as we maintain an optimistic attitude, it is bound to be able to infect each other's emotions, so that communication becomes easier. In addition, different types of people with disabilities have different characteristics, the legal clinic to provide legal aid should take into account the special characteristics of different persons with disabilities. Second, the clinic students should have a good professional quality. The cultivation of professional quality requirements of clinic science curriculum theory to undertake to the student culture, legal clinics should set the relevant theoretical knowledge of common cases, laws and regulations and the handling of ideas, involving disabled persons. The marriage and family law related techniques for handling cases, involving residual masses of non lawsuit parts handling skills, administrative litigation involving disabled people handling skills, disability rights and interests of consumers handling skills, disabled labor dispute case handling skills and theory course, a full range of cultivating students' professional quality, to enable students to can be completed for persons with disabilities to provide legal aid practice task. Third, the legal clinic should make clear the service standards, set the fixed terms. The service science of law clinic needs to observe the fixed procedure and the feasible plan to carry on, and cannot carry on the. Therefore, the legal clinics should set up rules and regulations for the disabled, and provide legal services to the disabled in accordance with the requirements of the regulations. 


\section{(3) the main contents of the legal clinic for the protection of the rights and interests of the disabled}

Legal clinic to protect the interests of disabled persons shall follow the following steps to carry out activities: first, it should open "disabled rights protection, legal clinic education" teacher selection, select teachers with rich experience in the theory and practice of teaching experience in Colleges and universities and for teachers were special training, special training includes not only legal clinic courses training, should also include the simple sign language training, disabled communication skills training. Second, in Colleges and universities to open "the protection of the rights and interests of the disabled - law clinic education" theory, to take the elite education, screening outstanding students to participate in the legal clinic. On the basis of the legal service center, the actual legal aid cases. Legal clinics should be carried out to receive the case for co-ordination arrangements, according to the provisions of the procedures for processing. In the process of handling legal aid cases, students should play a subjective initiative, in the case of occupy the dominant position, independently of the legal aid of the case in the original plan, only when students encounter confusion in practice after the encounter teachers to take part in, and in the handling of cases into the guide. Students should for persons with disabilities to develop solutions, of non litigation cases issue legal opinion book, so as to provide guidance for the protection of disabled people's rights, the lawsuit. Clinic students should provide a free agent or defender for the disabled. To provide legal aid to persons with disabilities, or to provide a proxy or defense in court. The case ended, students should be closed clinics and filing legal clinic cases do respond to archive. Third, to mobilize the enthusiasm of students to participate in the protection of the rights and interests of the disabled. The protection of the rights and interests of the disabled is not only limited to legal aid, while completing the task of the clinic course, students should be encouraged to participate in various volunteer activities, and contribute to the maintenance of the legitimate rights and interests of the disabled. Fourth, the legal clinic is not only a platform for students to carry out legal practice and strengthen the social practice ability, but also a place and base for students to conduct theoretical research. In order to protect the interests of persons with disabilities legal clinic as an example, the contractor real case is an important work in clinic of teachers and students, but handled the case at the same time, we should from summarizing experiences and lessons, through a specific case to understand the protection of persons with disabilities related security system, find the existing problems, put forward a sound proposal.

\section{Construction of the rights and interests of persons with disabilities to protect the significance of the law clinic}

Constructing the legal clinic for the protection of the rights and interests of the disabled is of great significance to the improvement of the education system and the construction of a harmonious society. First, building a legal clinic for the protection of the rights and interests of the disabled is conducive to the cultivation of students' good legal professional ethics, career, public welfare and mission, to promote the comprehensive development of the quality of students. Students in the participation of clinical legal education in the process of handling the case, not driven by economic interests, and undertake all disabled legal aid cases, prompting students positive efforts to secure the rights and interests of the disabled parties, is conducive to the cultivation of students' responsibility of the parties, is conducive to the students to pursue the real justice, to train students to participate actively in the spirit of the cause of disabled rights, which greatly promoted the Chinese law students form a good legal professional ethics.

Second, construction of the rights and interests of persons with disabilities to protect the legal clinic is conducive to the innovation of legal education, and promote the diversification of China's education reform and teaching methods. First of all, the legal clinic education makes the students, the social vulnerable groups and the law teachers form a good interactive relationship. Clinical students in the dual identity of the client and students to learn and social practice, which greatly inspired the enthusiasm of the students, and enhance the students' sense of ownership. Secondly, the legal clinic education has changed the way to evaluate students in the past, and to ease the antagonism between teachers and students, so that the relationship between teachers and students is more equal. Again, the 
legal clinic will be the focus of teachers from the theoretical teaching to the accumulation of legal practice experience. This has promoted the reform of our country's traditional legal education mode, so that our country's legal education can take a new step.

Third, enrich the construction system of China's legal clinics, and promote the comprehensive development of China's legal clinic education. At present our country University's legal clinic has the criminal law clinic mainly, the civil law clinic and the on-line legal clinic and so on. But at present domestic colleges and universities but did not have a dedicated disabled rights and interests protection law clinic. Therefore, the establishment of disabled rights protection law clinic very innovative, improve the China's system of legal clinics, for the promotion of clinical legal education in China's development has an important role.

\section{References}

[1] Zhen Zhen. The clinical legal education in China [M]. Beijing: Law Press, 2001

[2] Gao Jie. Legal clinic teaching content analysis - the disabled support raised to protect the rights and interests of the case for perspective [J]. Today Hubei (Management), 2013 (6)

[3] Wen Xuan. The clinical legal education [D]. Southwest University of Political Science and Law, 2010

[4]Mohammad Mahdi Meghdadi,Ahmad Erfani Nasab. The role of legal clinics of law schools in human rights education; Mofid University legal clinic experience [J]. Procedia - Social and Behavioral Sciences,2011,15.

[5] Xu Jian. Concept, organization and method of legal clinic [M]. Beijing: Peking University press, 2013

[6] Wen Xuan. The clinical legal education [D]. Southwest University of Political Science and Law, 2010 